\section{Feasibility of Improving Cucumber Yield without Chemical Control in Soils Susceptible to Nematode Buildup}

\author{
H.Y. Hanna, P.D. Colyer, T.L. Kirkpatrick ${ }^{1}$, D.J. Romaine, and \\ P.R. Vernon \\ Louisiana State University Agricultural Center, Louisiana Agricultural \\ Experiment Station, Red River Research Station, P.O. Box 8550, Bossier City, \\ LA 71113 \\ Additional index words. Cucumis sativus, Meloidogyne incognita, nematode-resistant \\ tomatoes, Lycopersicon esculentum, double-cropping, ethoprop
}

\begin{abstract}
Studies were conducted for 2 years in root-knot-nematode-infested soils to determine growth and yield response of 'Dasher II' cucumbers (Cucumis sativus L.) to double-cropping with nematode-resistant tomatoes (Lycopersicon esculentum Mill.), using nematode-free cucumber transplants and preplant treatment with ethoprop nematicide. Cucumbers grown following the nematode-resistant 'Celebrity' tomato during the same season produced significantly more plant dry weight, more fruit per plant, and higher premium and total yields than did cucumbers double-cropped with the nematodesusceptible 'Heatwave' tomato in both years. The cucumber produced longer stems in 1992 and fewer culls in 1993 following resistant tomatoes. Cucumber plants raised in nematode-free soilless mix for 3 weeks before transplanting produced significantly longer stems and more plant dry weight than did direct-seeded cucumbers in 1992, but not in 1993; however, they produced significantly higher premium yield in both years, and higher total yield, more fruit per plant, and fewer culls in 1993. Preplant treatment with ethoprop significantly increased cucumber stem length, dry weight, premium and total yield, and number of fruit per plant in 1992 but not in 1993. Ethoprop treatment had no effect on the percentage of culls in either year. Chemical name used: $O$-ethyl $S, S$-dipropyl phosphorodithioate (ethoprop).
\end{abstract}

Root-knot nematodes, Meloidogyne incognita (Kofoid \& White) Chitwood, cause significant losses in yield of many economic crops throughout the world. The Norwood sandy loam soil prevalent in the Red River Valley in northwestern Louisiana is prone to nematode buildup because of continuous farming with susceptible crops. Our attempts to plant cucumbers following cotton in 1992 had failed because of severe injury from root-knot nematodes. Recent preliminary studies by Hanna et al. (1993) indicated that soil samples collected from the test site before planting cucumbers had a population density of $\approx 5000$ M. incognita juveniles $/ 500 \mathrm{~cm}^{3}$ of soil.

Development of tomato cultivars resistant to root-knot nematodes is an effective, eco-

Received for publication 28 Dec. 1993. Accepted for publication 3 June 1994. Approved for publication by the director of the Louisiana Agricultural Experiment Station as manuscript no. 94-84-8015. We gratefully acknowledge the donation of tomato and cucumber seeds by Petoseed Co., Saticoy, Calif. Mention of a trademark, proprietary product, or vendor does not constitute a guarantee or warranty of the product by the Louisiana State Univ. Agricultural Center and does not imply its approval to the exclusion of other products or vendors that also may be suitable. The cost of publishing this paper was defrayed in part by the payment of page charges. Under postal regulations, this paper therefore must be hereby marked advertisement solely to indicate this fact.

${ }^{1}$ Southwest Research and Extension Center, Univ. of Arkansas, Hope, AR 71801.
Studies were conducted in Summer (July to October) 1992 and 1993 on a Norwood sandy loam soil (Typic Udifluvent; fine-silty, mixed, calcareous thermic) at the Red River Research Station in Bossier City, La. Planting dates, harvest period, air temperature, and rainfall during the test period in each year were recorded (Table 1). Plots planted with 'Celebrity' (nematode resistant) and 'Heatwave' (nematode susceptible) tomato cultivars were marked after the last harvest and sprayed with $\mathrm{N}$-(phosphonomethyl)glycine (glyphosate) at $3.4 \mathrm{~kg} \cdot \mathrm{ha}^{-1}$ to kill tomato plants and other existing vegetation. Two weeks after being treated with glyphosate, half of the tomato beds was treated with ethoprop (RHÔNEPOULENC, Research Triangle Park, N.C.) at $3.1 \mathrm{~kg} \cdot \mathrm{ha}^{-1}$ by injecting the chemical through the drip-irrigation system used previously to irrigate the tomatoes; the other half remained nontreated. 'Dasher II' blend cucumber hybrid (12\% Poinsett 76 pollinizer) was transplanted or direct-seeded 2 days after the ethoprop treatment. Transplants were raised in nematode-free soilless mix (Pro-Mix BX; Premier Brands, Yonkers, N.Y.) for 3 weeks before being planted in the field. The experimental design was a $2 \times 2 \times 2$ factorial, arranged in a randomized complete block with four replications in 1992 and three replications in 1993. Treatments were 1) cucumbers double-cropped with nematode-resistant vs. nematode-susceptible tomatoes, 2) transplanted vs. direct-seeded cucumbers, and 3) ethoprop-treated vs. nontreated soil. In 1992, cucumbers were transplanted or direct-seeded in $3 \times 6-\mathrm{m}$ plots, and plant in-row spacing was $30 \mathrm{~cm}$. In 1993, cucumbers were transplanted or direct-seeded in $1.5 \times 9-\mathrm{m}$ plots, and plant spacing was $45 \mathrm{~cm}$. Plants were trained vertically using tomato skeletons for support (Hanna, 1993). Cucumbers were fertilized by injecting $14 \mathrm{~kg} \mathrm{~N} / \mathrm{ha}(41.2 \mathrm{~kg}$ ammonium nitrate $34 \mathrm{~N}-0 \mathrm{P}-0 \mathrm{~K})$ through the drip-irrigation system when the plants reached the third leaf stage. Two more applications of equal amounts were made at 3-week intervals following the first application.

Stem length was measured on five plants per plot before the first harvest in 1992 and three plants per plot after the last harvest in 1993. Samples of the tops, without fruit, were oven-dried at $71 \mathrm{C}$ for 5 days and dry weights were determined. Transplanted and directseeded cucumbers were harvested three times each week for 5 weeks. Fruit were graded according to U.S Dept. of Agriculture standards (U.S Dept. of Agriculture, 1958) for U.S. Fancy, No. 1, No. 2, and culls. Premium yield was determined by combining the weight 
Table 2. Influence of previous tomato cultivar, method of plant establishment, and ethoprop on stem length and plant dry weight of cucumbers in 2 years.

\begin{tabular}{|c|c|c|c|c|}
\hline \multirow[b]{2}{*}{ Variable } & \multicolumn{2}{|c|}{ Stem length $(\mathrm{cm})$} & \multicolumn{2}{|c|}{ Dry wt (g/plant) } \\
\hline & 1992 & 1993 & 1992 & 1993 \\
\hline \multicolumn{5}{|c|}{ Tomato cultivar (previous crop) } \\
\hline Nematode resistant & 172 & 313 & 51.3 & 66.8 \\
\hline Nematode susceptible & 127 & 270 & 32.1 & 56.7 \\
\hline Significance & $* * *$ & NS & $* * *$ & $* * *$ \\
\hline \multicolumn{5}{|c|}{ Cucumber establishment method } \\
\hline Transplanted & 177 & 250 & 51.7 & 59.1 \\
\hline Seeded & 125 & 333 & 31.7 & 64.3 \\
\hline Significance & $* * *$ & $* *$ & $* * *$ & NS \\
\hline \multicolumn{5}{|l|}{ Ethoprop } \\
\hline Treated & 170 & 304 & 51.0 & 63.0 \\
\hline Nontreated & 130 & 280 & 32.4 & 60.4 \\
\hline Significance & $* *$ & NS & $* * *$ & NS \\
\hline Cultivar $\times$ ethoprop & $* *$ & NS & $* *$ & NS \\
\hline
\end{tabular}

of fruit graded Fancy and No. 1. Total yield was the sum of fruit graded Fancy, No. 1, and No. 2 by weight. Fruit number was the sum of the number of fruit graded Fancy, No. 1, and No. 2; the rest were culls.

\section{Results and Discussion}

Cucumbers, planted after the nematoderesistant tomato cultivar Celebrity, produced significantly longer stems in 1992 and more plant dry weight in both years than did cucumbers planted after the nematode-susceptible tomato cultivar Heatwave (Table 2). Premium and total yields and number of fruit per plant of cucumbers planted after the nematode-resistant tomato cultivar were significantly higher in both years and percentage of culls was significantly lower in 1993 than with the cucumbers planted after the nematode-susceptible tomato cultivar (Table 3 ).

The differences of stem length between transplanted and direct-seeded cucumbers were significant but not consistent from one year to the next (Table 2). Plant dry weight of transplanted cucumbers was significantly greater than direct-seeded cucumbers in 1992 but not in 1993 (Table 2). However, transplanted cucumbers produced significantly higher premium yields in both years, and more fruit per plant in 1993 than did direct-seeded cucumbers. No significant differences existed in total yields between transplanted and direct-seeded cucumbers in 1992, but the transplanted cu- cumbers tended to produce higher yields. Transplanted cucumbers produced significantly higher total yields and less culls than direct seeded in 1993 (Table 3).

Cucumbers planted in beds treated with ethoprop produced significantly longer stems, more plant dry weight (Table 2), higher premium and total yields, and more fruit per plant (Table 3) in 1992 but not in 1993, as compared to the nontreated controls. Ethoprop treatment had no effect on the percentage of culls in either year of this study (Table 3). Heavy rainfall after the ethoprop treatment in 1993 may have diluted the chemical in the soil and resulted in no yield improvement in the treated plots.

There was a significant cultivar $\times$ ethoprop interaction for stem length and plant dry weight in 1992 (Table 2) and a significant plant establishment method $\times$ ethoprop interaction for premium yield in 1992 and for percentage of culls in 1993 (Table 3). Other interactions

Currently, the use of many agricultural chemicals to control vegetable pests is being reviewed by the Environmental Protection Agency. Some of these chemicals possibly will be subject to more restricted use and new replacements will not be registered easily. Alternatives to chemical control of root-knot nematodes in cucumbers must be found. Those alternatives include resistant cultivars and improved cultural methods.

Previous research indicated that producing were not significant. trellised cucumbers double-cropped with tomatoes is possible (Hanna, 1993; Hanna et al., 1989). The results of this study indicate that growing cucumbers following a nematoderesistant tomato cultivar during the same season can be an effective cultural method to improve cucumber yields in soils that have a history of root-knot nematode problems. Hanna et al. (1993) reported that the number of rootknot nematodes found in cucumber plots previously planted with nematode-resistant tomatoes was significantly lower than the number found in plots previously planted with nematode-susceptible tomatoes. The use of cucumber transplants rather than direct seeding can enhance fruit yields. Transplant roots developed in nematode-free soilless mix may have allowed cucumber plants to withstand or resist nematode infection to a greater degree than direct-seeded plants. Also, using transplants may have reduced losses of plant stand and contributed to higher yields. Growing cucumbers from transplants can be costly, but technological advances in the greenhouse and in the field have held down production costs, making transplants an affordable option.

We suggest that double-cropping cucumbers with a nematode-resistant tomato cultivar and establishing cucumbers from transplants can be a viable alternative to soil treatment with nematicides for improving cucumber yield in root-knot-nematode-infested soil.

\section{Literature Cited}

Baker, J.D. 1977. Trellising cucumbers. Agr. Gaz. New South Wales 88(4):2-3.

Fassuliotis, G. 1967. Species of Cucumis resistant to the root-knot nematode. Meloidogyne incognita acrita. Plant Dis. Rptr. 51:720-723.

Fassuliotis, G. 1970. Resistance of Cucumis spp. to the root-knot nematode, Meloidogyne incognita acrita. J. Nematol. 2:174-178.

Fassuliotis, G. 1979. Plant breeding for root-knot nematode resistance, p. 425-453. In: J.N. Sasser and C.C. Carter (eds.). Root-knot nematodes (Meloidogyne species): Systematics, biology and control. Academic, New York.

Fassuliotis, G. 1982. Plant resistance to root-knot nematodes, p. 31-49. In: R.D. Riggs (ed.). Nematology in the southern region of the United States. Arkansas Agr. Expt. Sta., Fayetteville, Southern Coop. Serv. Bul. 276.

Fassuliotis, G. and G.J. Rau. 1963. Evaluation of

Table 3. Effects of previous tomato cultivar, method of plant establishment, and ethoprop on cucumber yield, fruit number, and percentage of culls in 2 years.

\begin{tabular}{|c|c|c|c|c|c|c|c|c|}
\hline \multirow[b]{3}{*}{ Treatment } & \multicolumn{4}{|c|}{ Fruit yield $\left(\mathrm{mg} \cdot \mathrm{ha}^{-1}\right)$} & \multirow{2}{*}{\multicolumn{2}{|c|}{$\begin{array}{c}\text { Fruit } \\
\text { (no./plant) }\end{array}$}} & \multirow{2}{*}{\multicolumn{2}{|c|}{$\begin{array}{c}\text { Culls } \\
(\%)\end{array}$}} \\
\hline & \multicolumn{2}{|c|}{ Premium } & \multicolumn{2}{|c|}{ Total } & & & & \\
\hline & 1992 & 1993 & 1992 & 1993 & 1992 & 1993 & 1992 & 1993 \\
\hline \multicolumn{9}{|c|}{ Tomato cultivar (previous crop) } \\
\hline Nematode resistant & 14.4 & 18.2 & 25.8 & 22.3 & 6.8 & 7.4 & 10.8 & 15.8 \\
\hline Nematode susceptible & 5.0 & 11.7 & 10.5 & 15.0 & 3.3 & 5.6 & 18.0 & 22.5 \\
\hline Significance & $* * *$ & $* * *$ & $* * *$ & $* * *$ & **** & $* * *$ & NS & $* * *$ \\
\hline \multicolumn{9}{|c|}{ Cucumber establishment method } \\
\hline Transplanted & 12.7 & 18.1 & 21.7 & 22.1 & 5.9 & 7.9 & 15.5 & 17.2 \\
\hline Direct seeded & 6.7 & 11.8 & 14.7 & 15.1 & 4.2 & 5.0 & 13.3 & 21.1 \\
\hline Significance & $* * *$ & $* * *$ & NS & $* * *$ & NS & $* * *$ & NS & $* *$ \\
\hline \multicolumn{9}{|l|}{ Ethoprop } \\
\hline Treated & 13.6 & 15.4 & 24.5 & 19.3 & 6.7 & 6.8 & 14.0 & 18.4 \\
\hline Nontreated & 5.8 & 14.4 & 11.8 & 18.0 & 3.4 & 6.2 & 14.8 & 19.9 \\
\hline Significance & $* * *$ & NS & $* *$ & NS & $* * *$ & NS & NS & NS \\
\hline Establishment $\times$ ethoprop & $* * *$ & NS & NS & NS & NS & NS & NS & $*$ \\
\hline
\end{tabular}

$\overline{\mathrm{Ns}, *, * *, * * * *}$ Nonsignificant or significant $\mathrm{F}$ test at $P \leq 0.05,0.01$, or 0.001 , respectively. 


\section{Crop Production}

Cucumis spp. for resistance to cotton root-knot nematode, Meloidogyne incognita acrita. Plant Dis. Rptr. 47:809.

Hanna, H.Y. 1993. Producing trellised cucumbers double-cropped with tomatoes. HortScience 28:96-98.

Hanna, H.Y., A.J. Adams, and R.J. Edling. 1989. Double-cropping cucumber and tomatoes to minimize the cost of staking cucumber. Proc. Fla. State Hort. Soc. 102:326-328.

Hanna, H.Y., A.J. Adams, and R.N. Story. 1987. Increased yield in slicing cucumbers with verti- cal training of plants and reduced plant spacing. HortScience 22:32-34.

Hanna, H.Y., P.D. Colyer, T.L. Kirkpatrick, D.J. Romaine, and P.R. Vernon. 1993. Improving yield of cucumbers in nematode-infested soil by double-cropping with a resistant tomato cultivar, using transplants and nematicides. Proc. Fla. State Hort. Soc. 106:163-165.

Konsler, T.R. and D.L. Strider. 1973. The response of cucumber to trellis vs. ground culture. HortScience 8:320-321.

Russo, V.M., B.W. Roberts, and R.J. Shatzer. 1991.
Feasibility of trellised cucumber production. HortScience 26:1156-1158

U.S. Department of Agriculture. 1958. United States standards for grades of cucumber. Agr. Mkt. Serv. 46 FR 63203.

Walters, S.A., T.C. Wehner, and K.R. Barker. 1993. Root-knot nematode resistance in cucumber and horned cucumber. HortScience 28:151-154.

Winstead, N.N. and J.N. Sasser. 1956. Reaction of cucumber varieties to five root-knot nematodes (Meloidogyne spp.). Plant Dis. Rptr. 40:272275. 